\title{
A mozgásos rekreáció helye és szerepe a gyógytestnevelésben részt vevố tanulók körében
}

\author{
The place and role of active recreation among the \\ students, who attend adaptive physical education
}

\section{ÖSSZEFOGLALÁS:}

Tudományos vizsgálatok sora igazolja, hogy egyre több fiatalkorúnál tapasztalhatunk olyan egészségkárosodást, ami miatt nem vagy csak részlegesen vehetnek részt az iskolai testnevelésben. A gyógytestnevelésre járó tanulók száma évről évre nő́, amihez nagyban hozzájárul a mozgásszegény életmód. Mivel a gyógytestnevelés nem minden tanuló számára egyenlő́en elérhető, ezért szükség van a szabadidő aktív, tudatos megszervezésére, ezzel kiegészítve a tanulók mozgásprogramját.

Kulcsszavak magyarul: gyógytestnevelés, rekreáció, gyógymozgás, rehabilitáció

\section{ABSTRACT:}

It is proven by several scientific researches, that such health damages are experienced by even more underaged people, that prohibit totally or partly the participation in physical education lessons at school. Numbers of the students, who attend adaptive physical education lessons, increase year by year, that is greatly due to the sedentary lifestyle. The adaptive physical education is not available equally for every student, so it is needed to schedule the free time actively by raising awareness, completing the students' physical activities. Keywords: adaptive physical education, recreation, exercise is medicine, rehabilitation

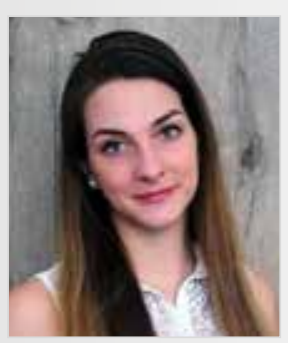

\section{Szerzo":}

ORSZÁG ALMA

gyógytestnevelő tanár Munkahelye: Bács-Kiskun Megyei Pedagógiai Szakszolgálat Kecskeméti Tagintézmény

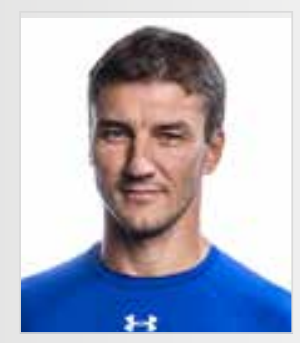

Rovatvezetô: POZSONYI ZSOLT

R-med Akadémia szakmai vezeto FTC Vízilabda erônléti edzô

\section{BEVEZETÉS:}

A KSH adatait elemezve megállapítottam, hogy egyre magasabb azon fiatalkorúak száma, akiknél olyan megbetegedést tapasztalhatunk, ami miatt részlegesen vagy teljesen kirekesztődnek az iskolai testnevelésórákról (KSH, 2017). A gyógytestnevelés hivatott áthidalni azt a szakadékot, ami a kimaradó tanulókat elválasztja egészséges társaiktól (Simon IÁ, Kajtár G 2017).

A gyógytestnevelés a betegségek megelőzésével és gyógyításával foglalkozó tudományág, amely a testnevelés módszereit használja fel (Nemessuri és mtsai, 1975). Bizonyított, hogy a mozgás valóban gyógyszerként funkcionál, ezért annak teljes eltiltása tovább károsíthatja az érintett gyermekeknek az egészségi állapotát ( $A M A$ et $A C S M$, 2007). A gyógytestnevelésre járó tanulók száma évről évre nő, amihez szignifikánsan hozzájárul a fiatalok egészségmagatartásának romló tendenciája (Fügedi, 2018).

A genetikailag determinált betegségek mellett egyre több tanulóra jellemzőek az életmódból fakadó betegségek kialakulása, mint az obezitás, a magas vérnyomás, a nem megfelelő koordinációs és kondicionális képességek, a hanyagtartás és a funkcionális gerincferdülés (KSH, 2017. 1. táblázat).

Az iskolákban bevezetett mindennapos testnevelés program nem javította a tanulók egészségtudatosságát (Fintor, 2017), sőt egyes esetekben főként a meglévô infrastruktúra hiányosságai miatt rontották a testnevelésórák pozitív megítélését. Fenti okból kifolyólag sok gyerek nem szereti meg az iskolában a mozgást, negatív élményként épül be mindennapjaikba, amitől a kötelezettségek múlásával tudatosan szabadulni akarnak (Ország, 2017).

A fiatalkorúak egészségmagatartásának romló tendenciája azt eredményezi, hogy nagyobb lesz a kockázat a már említett életmódból fakadó betegségek kialakulására és azok súlyosbodására. Azok a gyógytestnevelésre érkező tanulók, akiknek súlyosabb elváltozásuk van, a tanórákon kívül más mozgásterápiás kezeléseken is részt vesznek.

A gerincelváltozások kezelésében a legismertebb módszer a Schroth terápia, amelynek a lényege, hogy a 3 dimenziós szemlélettel a csigolyaoszlopot olyan korrekciós helyzetbe állítja, hogy az elérje a maximális aktív megnyúlást, majd ebben a helyzetben tartva alkalmaz speciális légző és izometriás erősítő gyakorlatokat (Bezalel, Kalichman, 2015). Izometriás gyakorlatnak azt nevezzük, amikor az izom úgy fejt ki erőt, hogy közben az izom hossza nem változik (Dubecz, 2009).

A háziorvosi és a házi gyerekorvosi szolgálathoz bejelentkezettek tízezer megfelelő korú lakosra jutó száma fóbb betegségek szerint

Gyermekek (0-18 éves) fiúk, leányok együtt

\begin{tabular}{|c|c|c|c|c|c|c|c|c|}
\hline etegségek-illne & 2003 & 2005 & 2007 & $200 s$ & 2011 & 2013 & 2015 & 2017 \\
\hline $\begin{array}{r}\text { Cukorb } \\
\text { Dia }\end{array}$ & 12,5 & 13,8 & 16,6 & 20,4 & 22,9 & 23,6 & 25,5 & 27,4 \\
\hline $\begin{array}{r}\text { Mage } \\
\text { Hy }\end{array}$ & 41,6 & 46 & 53,1 & 62,5 & 64,5 & 62,9 & 64,7 & 59 \\
\hline $\begin{array}{l}\text { eformáló hátgerinc- } \\
\text { elváltozások-Spinal } \\
\text { impairments }\end{array}$ & 212,1 & 231,3 & 260,6 & 246 & 267,6 & 294,5 & 318,3 & 31 \\
\hline & & & & & & & 6 & \\
\hline
\end{tabular}

1. táblázat: A háziorvosi és a házi gyerekorvosi szolgálathoz bejelentkezettek tízezer megfelelő korú lakosra jutó száma föbb betegségek szerint

(Forrás: KSH http://www.ksh.hu/thm/2/indi2_8_1.html)

1. table: Numbers of the family doctors and pediatrician service registrated regarding

to ten thousand similar aged people according to their main sicknesses (Source: $K S H$ http://www.ksh.hu/thm/2/indi2 8 1.html) 
A belgyógyászati és ortopédiai betegségek kezelésében egyaránt kiemelt szerepe van a gyógyúszásnak, ami annak köszönhető, hogy igen intenzív edzésmunka végezhető a vízben, az ízületek és a csontok erős megterhelése nélkül. A gyógyúszás a víz leküzdésén és használatán alapszik, ezért fejt ki speciális hatást a szervezetre. A gyógyúszás a gyógytestnevelés részeként és különálló egészségügyi ellátásként is elérhető Magyarországon (Ország, 2017).

A gyógytestnevelés törvényi hátterét a múvelődési és közoktatási miniszter 11/1994. (VI.8.) rendelete a nevelési-oktatási intézmények múködéséról 142. § (1) és a 15/2013. (II. 26.) EMMI rendelet a pedagógiai szakszolgálati intézmények múködéséről határozza meg. Mivel a gyógytestnevelés kiscsoportos formában múködik, ahol egy tanórán egyszerre legfeljebb 16 tanuló vehet részt, ezért sokszor nincs lehetőségük a tanulóknak a megfelelő számú gyógytestnevelés-órán való részvételre. Ez fóként vidéken figyelhető meg a szakemberhiány miatt. Az ellátottság hiányai teszik szükségessé, hogy a gyógytestnevelők és a szülők közösen olyan lehetőségeket keressenek, ahol a gyerekek a számukra legmegfelelőbb módon egészíthetik ki a mozgásprogramjukat.

\section{ANYAG ÉS IMÓDSZER:}

Kutatásom célja megismerni a gyógytestnevelésre járó tanulók rekreációs szokásait, és elemezni azokat egyes környezeti tényezők alapján. A mintavétel $(n=70)$ során igyekeztem a lehető legváltozatosabb környezetből gyógytestnevelésre járó tanulókat szülői segítséggel megszólítani. Az idő rövidsége, a minta nagysága és a földrajzi távolság miatt a megválaszolásához írásbeli kikérdezést választottam elektronikus kérdőív formában. A kérdőív összeállítása önálló munka, és 10 teszt szerepel benne. Statisztikához EXCEL programot használtam.

A felmérésben zárt végü egy- és többkimenetelű kérdéseket, attitûdskálát és egyszerű információkra vonatkozó teljesen nyitott kérdéseket alkalmaztam, hogy azok a tanulók, akik még nem töltöttek ki kérdőívet, is pontos választ tudjanak adni, illetve hogy kevesebb hibás válasz érkez-

\section{Szülők és gyerekek sportolási szokásainak összefüggése}
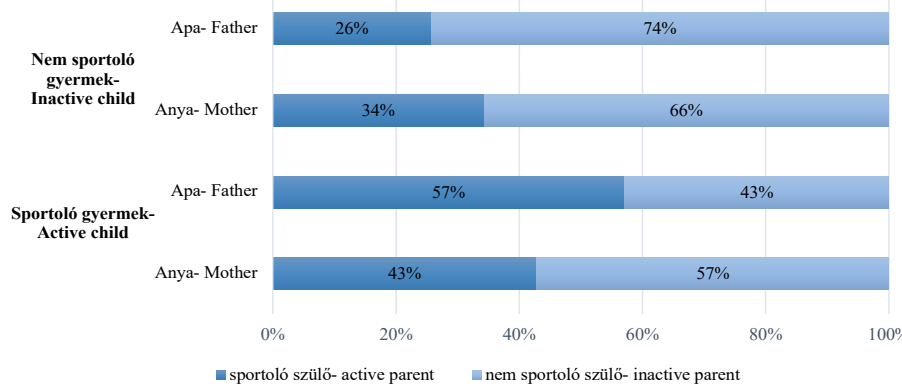

2. ábra: Szülők és a gyerekek sportolási szokásainak összefüggése (Forrás: Saját kutatás)

2. illustration: Connection between parents and children sport habits (Soure: Personal research) zen vissza. Az összefüggések vizsgálatához a következő feltevéseket állítottam:

\section{HIPOTÉZISEIM:}

1. A gyógytestnevelésre járó tanulók egy része nem kapja meg a törvényben előírt óraszámot.

2. A szülők fizikai aktivitása befolyásolja a gyerekek fizikai aktivitását.

3. A gyógytestnevelésre járó tanulók körében az aerob tevékenységek, ezen belül is egyszerü ciklikus mozgások a leggyakrabban előforduló mozgásformák.

4. A gyerekek szívesen próbálnak ki új mozgásos tevékenységeket, főként a természetben üzhető és extrém sportok kipróbálása kívánatos a tanulók számára.

\section{AINENER:}

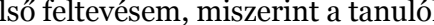
jt: a megkérdezett tanulók 77,10\%-a gyógytestnevelésben (1. diagramm).

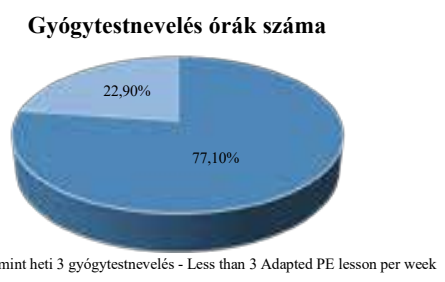

Heti 3 gyógytestnevelés - 3 Adapted PE lesson per week

1. ábra: A gyógytestnevelés-órák száma (Forrás: Saját kutatás)

2. illustration: Numbers of Adapted Physical

cation lessons (Source: Personal research) eredményhez hozzátartozik, hogy Budapesten ennél sokkal hatékonyabban múködik a gyógytestnevelés, a megkérdezetteknek csak 7\%-a él a fóvárosban. Ezért meg kell állapítsam, hogy az első hia gyógytestnevelésre járó tanulók sokaságát nem megfelelően jellemzi.

Ettől függetlenül megállapítom, hogy a kapott értékek alátámasztják azt a megállapítást, miszerint a formális oktatás mellett kiegészítő informális mozgásprogramot kell kidolgozni a tanulók számára.

A második feltevésem a szülők és a gyermekük sportolási szokásainak az öszszefüggésére mutat rá. $\mathrm{Az}$ egészséges életmódra nevelés legfontosabb eszköze a felnőttek, kiemelten a szülők példamutatása. $\mathrm{Az}$ ő minta értékű tevékenységük szükséges a nevelési folyamat eredményességének elérése érdekében (Szikora, 2018). A beérkező válaszok alapján a tanulók fele végez csak mozgásos tevékenységet szabadidejében. Mind a sportoló, mind a nem sportoló gyerekek esetében megfigyelhető, hogy a gyerekek sportolási szokásait dominánsan az apa sportolási szokásai befolyásolják. Tehát azokban a családokban, amelyekben az apa aktív, ott a gyerekek is nagyobb számban mutatnak aktivitást, ellenben ha az apa inaktív, a gyerekek is kisebb valószínűséggel sportolnak a szabadidejükben (2. diagramm). Azokban a családokban, ahol mindkét szülő sportol, a gyerekek $89,4 \%$-a szintén sportol, ami bizonyítja a szoros összefüggést a szülők és a gyerekeik sportolási szokásai között.

A harmadik feltételezésem a tanulók mozgással kapcsolatos szokásaira vonatkozott, melyet az ajánlások alapján állítottam fel. A legfontosabb szempont a gyógytestnevelésre járó tanulók rekreációjában az aerob mozgásformák múvelésének biztosítása.

Aerob mozgásformának nevezzük a mérsékelt erôteljességi övezetben végzett ciklikus mozgásokat, amelyekben az oxigénfelvétel mennyisége megegyezik az oxigénigénnyel (Pavlik, 2011). A válaszadók által leggyakrabban végzett rekreációs sporttevékenységek a gyaloglás, kerékpározás, úszás, futás, labdajátékok, aerobik, tánc és a jóga (3. diagramm).

$\mathrm{Az}$ 1-4 leggyakrabban végzett mozgás valóban aerob, ciklikus mozgás, ami javítja a tanulók fittségi állapotát. „Fittségen olyan pszichés és fizikai állapotot értünk, mely az egészséget és a minőségi életet előtérbe helyezve magába foglalja az általános jó közérzetet és a megnövekedett mindennapi teljesítőképességet.

A fittség állapota nem szükségszerüen ugyanaz mindenki számára, ebben erős egyéni eltérések lehetnek. Fitt az, aki többek között a tőle elvárható munkaképességgel rendelkezik és Kenneth Cooper szavaival élve »tökéletes közérzet «-nek örvend" (Rétsági és mtsai, 2011).

A negyedik feltevés arra irányult, hogy a tanulók szívesen próbálnának ki új rekreációs sporttevékenységet, és ha igen, mely sportok kipróbálása kívánatosabb a tanulók számára. Az iskolás korosztály rekreációjában nagy szerepet játszik a kortársak véleménye. A gyerekek olyan tevékenységeket részesítenek előnyben, ami divatos, ilyenek például az extrém sportok, amiben az ember bizonyíthatja bátorságát, rátermettségét a többiekkel szemben.

A felmérés egyértelmúen kimutatja, hogy az általam vizsgált tanulók is nagy hajlandóságot mutatnak az extrém sportok kipróbálására.

A szezonális sportokra, azon belül a téli sportokra érkezett a legtöbb visszajelzés, amiben szerepet játszik az a tény, hogy a tanulók felmérése téli időszakban történt meg. A téli sportok közül is magasan a síelés kipróbálására érkezett a legtöbb válasz. A tanulók fő motivációja a kortársaknak való megfelelés mellett az élményszerzés. 


\section{Tanulók gyakori rekreációs tevékenységei}

aerobik, tánc, jóga - aerobics, dance, yoga

labdajátékok- ball games

$$
\begin{aligned}
& \text { futás- running } \\
& \text { úszás- swimming }
\end{aligned}
$$

kerékpározás- cycling

gyaloglás, túrázás- walking, hiking
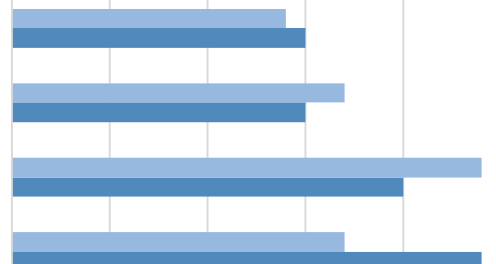

- Havonta többször- Several times a month

$10 \% \quad 15 \% \quad 20 \% \quad 25 \% \quad 30 \%$ $35 \%$

3. ábra: Tanulók gyakori rekreációs tevékenységei (Forrás: Saját kutatás)

3. illustration: Common recreation activities of Students (Soure: Personal research)

\section{IKÖVETKEZTETÉSETK:}

A gyógytestnevelésre járó tanulók fizikai rekreációja fontos szerepet tölt be az egészségi állapotuk javításában. A szülők támogató és példamutató szerepe kiemelten szükséges a gyerekek egészéges életmódjának kialakításában.

Az aerob mozgásformák, mint a gyaloglás, futás, úszás, kerékpározás jelen van a tanulók mindennapjaiban, javítva ezzel a fittségüket. A mozgás szeretetének fenntartása érdekében a szülők és a gyerekkel foglalkozó sportszakemberek feladata az új és kívánt sportágmozgások megtanítása és új élmények biztosítása.

$\mathrm{Az}$ extrém sportok előkészítő gyakorlatait, akadálypályákon való átjutást, szabadban végezhető mozgásformákat szívesen gyakorolják a gyerekek. „A jól megválasztott, szakszerűen végzett, rendszeres sporttevékenységnek életünk részévé kell válnia, növelnie kell egészségérzetünket, javítani a közérzetet. Ezáltal több betegséget, ártalmat tudunk megelőzni, sőt bizonyos betegségek esetén a terápia része lehet” (Pavlik, 2015. 25. o.).

Az egészséges életmód szorosan kötődik a rekreációhoz. A rekreáció egy folyton változó, fejlődő, a kor kihívásainak megfelelő, környezettől, társadalomtól, közösségtől és egyéntől függő dinamikus rendszer. (Fritz: Alapfogalmak és jelentéseik a rekreáció területén: Rekreáció mindenkinek III., 2019). A rekreáció célrendszerében és filozófiájában benne foglaltatik az egészség megőrzése, helyreállítása (Révész és mtsai, 2015).

A mozgásos rekreáció célja az egészség megőrzése, fejlesztése, a testi-lelki jólét megteremtése, s hogy az alkalmazott módszereket e cél elérése érdekében használjuk. A mozgásos rekreáció olyan gyakorlatok végrehajtásából álló tevékenység, melynek célja az egyén egészségének megőrzése és fejlesztése, teljesítőés munkavégző képességének helyreállítása és szükség szerint annak növelése. (Fritz: Alapfogalmak és jelentéseik a rek- reáció területén: Rekreáció mindenkinek III., 2019).

2018 decemberében kiadtak egy átfogó tanulmányt, melyben 20 vizsgálat eredményeit hasonlították össze. Az összehasonlítás során a 3-12 éves korú óvodás és iskolás gyerekek mozgásprogramjának hatékonysága állt a fókuszban.

A kutatás egyértelmúen kimutatta, piratorikus fittség szignifikáns növekedéséhez vezettek. A megfigyelt gyerekek aerob mozgásformái a gyaloglás, és a futással egybekötött játékok, labdázás, ugrálás, mászás, tánc volt (Pozuelo-Carrascosa DP et al. 2018).

Ez igazolja azt a törekvésünket, hogy a gyógytestnevelésen részt vevő tanulóknak a fizikai rekreációra az aerob mozgásformákat ajánljuk, hogy ezáltal javuljon a gyerekek fittsége és egészségi állapota.

\section{IRODALOIMJEGYZÉK}

American Medical Association (AMA) and the American College of Sports Medicine (ACSM) (2007) Exercise is Medicine (EIM)

http://mozgasgyogyszer.hu/hu/mozgasegeszseg/eim_europaban_es_a_vilagban.html

Fügedi Balázs (2018): Az egészségnevelés tudományterületi szintézise DOI: 10.15773/EKE.HABIL.2018.005

Fintor Gábor (2017): A mindennapos tanórai testnevelés szubjektív helyzete az észak-alföldi réhogy az aerob mozgásformák kardio-res- gió tanulóinak körében. Magyar Sporttudományi Szemle, 18. évf. 72. sz. 4-10. o.

Dubecz József (2009): Általános edzéselmélet és módszertan

KSH (2017): A társadalmi haladás mutatószámrendszere 2.8.1. Egészségi állapot (2003-2017) táblázat

http://www.ksh.hu/thm/2/indi2_8_1.html (letöltve 2019. 01. 22.)

Lőkös Dániel (2014): A csoportos gyógyúszás hatása a tartáshibás fiatalok szorongására, testi énképére és mozgásos ügyességére. DOI:10.14753/SE.2014.1972

Nemessuri M., Gárdos M., Uzonyi Gy., Kálmán P, Lukács L., Mónus A., Páldi Gy., Csider L., Harmath Á., Czigány F., Csider T., Dékány P., Rimaszombati K., Záborszky B. (1975): Iskolás korú gyermekek gyógytestnevelése

Ország Alma (2017): A rendszeres testnevelés és az úszás kapcsolata, egymásra való hatása gimnazista tanulóknál

Pavlik Gábor (2015): A rendszeres fizikai aktivitás szerepe betegségek megelőzésében, az egészség megőrzésében. Egészségtudomány, LIX. évfolyam, 2015. 2. szám 11-26. o.

Pavlik Gábor (2011): Élettan-Sportélettan

Pál, K., Császár, J., Huszár, A. és Bognár, J. (2005): A testnevelés szerepe az egészségtudatos magatartás kialakításában. Új Pedagógiai Szemle, 6: 25-32.

Pozuelo-Carrascosa DP, García-Hermoso A,(2018): Effectiveness of school-based physical activity programmes on cardiorespiratory fitness in children: a meta-analysis of randomised controlled trials. Br J Sports Med. 2018; 52: 12341240. doi:10.1136/bjsports-2017-097600

Rétsági Erzsébet, H. Ekler Judit, Nádori László, Woth Péter, Gáspár Mihály, Gáldi Gábor, Szegnerné Dancs Henriette (2011): Sportelméleti ismeretek

Révész László, Müller Anetta, Herpainé Lakó Judit, Boda Eszter, Bíró Melinda (2015): A rekreáció elmélete és módszertana 1 . A rekreáció kialakulása, története, a rekreáció felosztása 17-20. o.

Simon IÁ, Kajtár G. (2017) A gyógytestnevelés jelentősége a szekunder rehabilitáció és egészségfejlesztés folyamatában - A megújulás szükségessége és irányai. Egészségfejlesztés, LIX. évfolyam, 2018. 1. szám. doi: 10.24365/ef.v59i1.222

Simon IÁ, Kajtár G. (2016): A gyógytestnevelés-órán alkalmazott sajátos gyógytestnevelő tanári módszerek. Magyar Sporttudományi Szemle. 2016; 17(66):58

Szikora Zsombor (2018): A sportos életmódra nevelés szerepe a prevencióban

Tomer Bezalel, Leonid Kalichman (2015): Improvement of clinical and radiographical presentation of Scheuermann disease after Schroth therapy treatment. DOI:https://doi.org/10.1016/j. jbmt.2014.04.008

\section{Tanulók által kívánatos rekreációs tevékenységek}

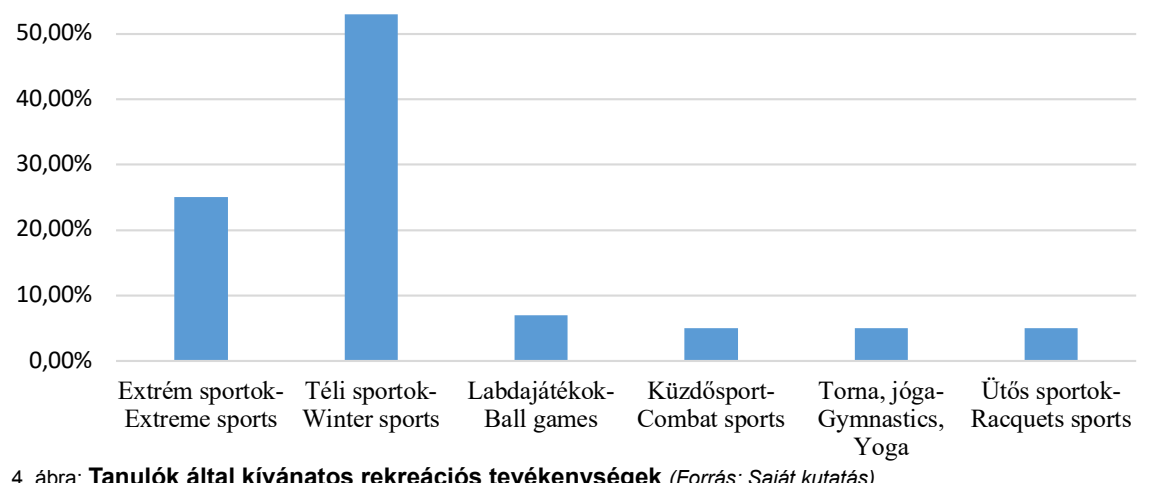

4. ábra: Tanulók által kívánatos rekreációs tevékenységek (Forrás: Saját kutatás)

4. illustration: Wanted recreation activities of Students (Soure: Personal research) 